\title{
EFFECTS OF NATURE TRAINING PROJECTS ON ENVIRONMENTAL PERCEPTION AND ATTITUDES
}

\author{
KORKMAZ, M. ${ }^{*}-$ FAKİR, H. $^{2}-$ ALKAN, H. $^{1}$ \\ ${ }^{I}$ Department of Forest Economics, Faculty of Forestry, Suleyman Demirel University \\ 32260 Isparta, Turkey \\ ${ }^{2}$ Department of Forest Botany, Faculty of Forestry, Suleyman Demirel University \\ 32260 Isparta, Turkey \\ *Corresponding author \\ e-mail: mehmetkorkmaz@sdu.edu.tr; phone: +90-246-211-3951; fax: +90246-211-3948 \\ (Received $11^{\text {th }}$ Jul 2017; accepted $6^{\text {th }}$ Dec 2017)
}

\begin{abstract}
Environmental education aims to create positive and environmental-sensitive perceptions, attitudes and behaviours toward environmental protection. This education primarily focuses on changing the attitudes and behaviours of students, rather than transferring information. Nature training projects provide improving methods to impart information on nature and environment in formal education programmes and develop people that are sensitive to society and environment. In 2014, a project titled "Judas Trees Are Blooming" was implemented in Turkey with the participation of secondary school $6^{\text {th }}$ grade students. The aim of the project was to create positive perception and attitudes regarding nature, forests and the environment. This study investigated and determined the effects of nature training projects on environmental perception and attitudes of secondary school students using the above-mentioned project as a case study. Students that participated in the project had more positive environmental perception and attitudes compared to those who did not participate according to questionnaires and observations given during the project. These positive environmental perceptions and attitudes are the benefits of forests, the importance of plants for our life, the mysteries of the worlds of plants and insects, nature and environmental protection and photosynthesis. Furthermore, the project provided positive contributions for raising awareness and improving the interest and knowledge of the participants regarding nature and the environment.
\end{abstract}

Keywords: environmental education, practical training, environmental protection, nature conservation, Turkey

\section{Introduction}

The environment is a physical, biological, social, economic and cultural setting in which people and other organisms sustain relationships throughout their lives and interact mutually. Environmental protection is of crucial importance and precious for the survival of organisms. Today, it is understood that the globalization of environmental problems can only be solved by changing people's behaviours. This can be accomplished by developing desired skills, knowledge, attitudes and behaviours in cognitive, affective and behavioural domains (Geray, 1998; Erten, 2005; Çimen and Y1lmaz, 2014; Milton et al., 1995; Poortinga et al., 2004). Specifically, these behavioural changes can be achieved through environmental education and nature training (Güven, 2014).

In comparison, "shallow environmentalist" approaches that disregard human-nature relationships, do not adequately focus on formal and non-formal education, and ignore participation do not suffice in achieving an effective environmental and nature education (Tlert, 1998; Noughton et al., 2005). However, formal education programs in developing countries are also known to be inadequate in terms of nature-environmental 
education. This is the case even though considerably positive changes have been achieved in society through environmental/nature education (Malone and Tranter, 2003; Güler, 2009). The effects of nature training are popular contemporary themes being studied in developed countries (Ogurlu, 2016).

When provided in a natural setting, a well-structured environmental and nature education is important to ensure that people see life by establishing an emotional bond with nature. This approach increases their interest and develops desired behaviours (Palmberg ve Kuru, 2001; Phenice and Griffore, 2003; Atasoy, 2006; Güler, 2009).

Nature training projects offer significant opportunities to create an active mass of people that have the potential to contribute to the promotion and protection of nature and natural assets. These projects play an important role in improving conceptual and practical knowledge and awareness among participants. The projects aim at ensuring that events and facts are understood from a scientific perspective and engage people to emerge them from a passive position to the position of "doing-experiencing". This is done by assigning active duties to participants, which enables them to experience meaningful learning (Alkan and Ogurlu, 2014).

Primary and secondary school is the main legal institution that responsible for providing education to members of society and serves as a genuine criterion to assess the development level of countries (Harlen and Qualter, 2014). In other words, secondary school is the most effective institution that shapes the personality of a child, gives direction to her/his future and creates the infrastructure for a robust development (Yıldırım and Köklükaya, 2016). In this context, a well-structured environmental and nature education that focuses on the importance of secondary school education is important to raise consciousness in future generations.

Child-oriented environmental education can ensure that environmental information is transferred to the next generation and triggers targeted behavioural changes (Damerell et al., 2013). Studies show that current environmental education offered at schools in Turkey are insufficient (Soran et al., 2000; Y1lmaz et al., 2002; Tanriverdi, 2009; Zengin and Kunt, 2013; Alkan and Ogurlu 2014). Therefore, non-formal nature training projects are important for addressing this gap. The aim of this study was to determine the effects of nature training projects on the environmental perception and attitudes of secondary school students in Turkey.

\section{Project description}

The "Judas Trees Are Blooming" project was implemented in Isparta-Turkey with the support of The Scientific and Technological Research Council of Turkey (TUBITAK). The Judas tree (Cercis siliquastrum) is a small deciduous tree that can grow up to 4-5 m long and has a wide crown. The most important characteristic of Judas tree is that it bears flowers directly on its trunk. Its pink-purple flowers that bloom in spring can be recognized easily in nature (Davis et al., 1970; Mamikoglu, 2007). Secondary school education is one of the most important stages after primary education for the development of a child in all aspects. The behaviours acquired in this period can be permanent. Therefore, an effective environmental and nature education that is provided during secondary school will ensure the acquisition of permanent behaviours. Just as Judas trees are easily recognized in nature, students who receive nature training will be easily recognized in the society. For that reason, the title of the project was "Judas Trees Are Blooming". Sixty $6^{\text {th }}$ grade students at the same secondary school who 
were randomly selected participated in the project. Under the project, training courses were delivered for seven days to groups of 30 students.

During the project, the participants were given instruction about the world of plants (recognition and classification, usage areas, endemic plants, etc.), the world of insects, ecosystems, importance of forests for our life, photosynthesis, importance of environmental protection and nature tourism. Throughout this curriculum, the goal was to create positive perception and attitudes regarding nature, forests and the environment. The training courses were delivered in practical form at the Botanic Garden and Herbarium Research and Applied Centre of Süleyman Demirel University and Isparta Kovadaçayı Arboretum. During the training courses, students were asked to draw pictures about plants and participated in activities that were held in a natural environment.

\section{Methodology}

Study data about environmental perception and attitudes were collected through questionnaires. Pre-evaluation and post-evaluation questionnaires were applied to test for change in the knowledge level of the students who participated in the project courses. The post-evaluation questionnaire contained questions about perceptions and attitudes regarding nature, forests and the environment. A three-point Likert scale (I agree, neutral, I disagree) was used to enable the students to answer the questions. The Cronbach alpha value was 0.824 . The internal consistence coefficient was found to be greater than 0.8 ; therefore, the scale that was used had a statistically high reliability. Post-evaluation questionnaires were also given to students in the same class who did not participate in the training courses provided under the project. This was done to explore the effects of the training on changes in perception and attitudes regarding nature, forests and the environment.

Since the data from the questionnaires were non-parametric (Kolmogorov-Smirnov test, $\mathrm{p}<0.05)$, the differences in the knowledge level of the students participating in the project before and after the training were found through a chi-square test. The MannWhitney $U$ test was used to identify differences in the perception and attitudes of those students who received training and those who did not.

\section{Result and Discussion}

\section{Characteristic of the students}

The sex and age distribution of the students who participated in the training project and those who did not is presented in Table 1.

Table 1. Student characteristics

\begin{tabular}{llll}
\hline Characteristics & & A $^{*}$ & B $^{*}$ \\
\hline \multirow{3}{*}{ Gender } & Girl & 31 & 32 \\
& Boy & 29 & 28 \\
& Total & 60 & 60 \\
\hline \multirow{2}{*}{ Age } & 11 & 36 & 34 \\
& 12 & 24 & 26 \\
& Total & 60 & 60 \\
\hline
\end{tabular}

*A: Students who participated in the project, B: Students who did not participate in the project. 
As understood from the table, the sex distribution of the students who participated in the project (A) and those who did not (B) is balanced. Students were between 11 and 12 years old.

\section{Difference in knowledge levels before and after the nature training}

The effect of the project on the knowledge level of the students was determined through the pre-evaluation and post-evaluation questionnaires given to the students who participated in the training project. Their knowledge levels with respect to knowing plant names, ability to classify plants, reproduction and growth styles and the concepts of ecosystem and endemic were compared.

Table 2 shows that the knowledge levels in the relevant areas improved at the end of the project. The increase was more pronounced in their knowledge level with respect to knowing plant names, ability to classify plants and the concepts of ecosystem and endemic (Chi-square test, $\mathrm{p}<0.05$ ). The difference in knowledge levels regarding plant reproduction was not statistically significant according to the chi-square test ( $p>0.05)$. This was because the students had already received training on that subject matter prior to the project. The most important differences were found in the concepts of ecosystem and endemic. Previously, none of the students had heard about the concept of endemic. Similarly, the number of students who knew the meaning of ecosystem was low prior to the project $(6.7 \%)$. Knowledge level for the concepts of endemic and ecosystem increased by $95 \%$ and $92 \%$, respectively after the project (Table 2).

Table 2. Difference in knowledge level before and after the nature training

\begin{tabular}{|c|c|c|c|c|c|c|}
\hline \multirow[t]{2}{*}{ Subject } & \multirow{2}{*}{$\begin{array}{c}\text { Time of } \\
\text { questionnaire }\end{array}$} & \multicolumn{3}{|c|}{ Options (\%) } & \multirow{2}{*}{$\begin{array}{c}\text { Chi-square } \\
\left(\mathbf{X}^{2}\right)\end{array}$} & \multirow[t]{2}{*}{$\mathbf{p}$} \\
\hline & & Yes & & No & & \\
\hline \multirow{2}{*}{$\begin{array}{l}\text { Know the names of plants } \\
\text { in the environment }\end{array}$} & The end of the project & 95.0 & $\boldsymbol{\Delta}$ & $5.0 \mathrm{~V}$ & \multirow{2}{*}{30.470} & \multirow{2}{*}{$0.000^{*}$} \\
\hline & Before the project & 50.0 & & 50.0 & & \\
\hline \multirow{2}{*}{ Able to classify plants } & The end of the project & 100 & $\Delta$ & $-\nabla$ & \multirow{2}{*}{26.939} & \multirow{2}{*}{$0.000^{*}$} \\
\hline & Before the project & 63.3 & & 36.7 & & \\
\hline \multirow{2}{*}{$\begin{array}{l}\text { Know how plants } \\
\text { reproduce }\end{array}$} & The end of the project & 98.3 & $\Delta$ & $1.7 \boldsymbol{\nabla}$ & \multirow{2}{*}{2.807} & \multirow{2}{*}{0.103} \\
\hline & Before the project & 91.7 & & 9.3 & & \\
\hline \multirow{2}{*}{ Know how plants grow } & The end of the project & 98.3 & $\boldsymbol{\Delta}$ & $1.7 \boldsymbol{\nabla}$ & \multirow{2}{*}{6.982} & \multirow{2}{*}{$0.008^{*}$} \\
\hline & Before the project & 85.0 & & 15.0 & & \\
\hline \multirow{2}{*}{$\begin{array}{l}\text { Know the concept of } \\
\text { endemic }\end{array}$} & The end of the project & 95.0 & $\Delta$ & $5.0 \nabla$ & \multirow{2}{*}{108.571} & \multirow{2}{*}{$0.000^{*}$} \\
\hline & Before the project & 0.0 & & 100 & & \\
\hline \multirow{2}{*}{$\begin{array}{l}\text { Know the concept of } \\
\text { ecosystem }\end{array}$} & The end of the project & 98.3 & $\Delta$ & $1.7 \nabla$ & \multirow{2}{*}{101.086} & \multirow{2}{*}{$0.000^{*}$} \\
\hline & Before the project & 6.7 & & 93.3 & & \\
\hline
\end{tabular}

${ }^{*} \mathrm{p}<0.05, \boldsymbol{\Delta}$ : increase, $\boldsymbol{\nabla}:$ decrease

According to the evaluation regarding the efficacy of the training project, the students reported that the topics addressed in the project were sufficient by $96.7 \%$. The students were also asked to evaluate the trainers and $98.3 \%$ of the students found that the trainers were competent in the training.

All of the students indicated that the plant species were explained adequately to them and that a sufficient number of plant sample was shown to them. The plant games were found to be sufficient by $98.3 \%$.

While $28.3 \%$ of the students stated that the training project slightly changed their perspective and knowledge level about plants, $81.7 \%$ of the students indicated that their 
perspective and knowledge level completely changed. The training project satisfied all student expectations. All of the students stated that their knowledge about plants and nature improved and thus the project was useful for them. Those students who were highly satisfied with the project were observed to be willing and enthusiastic about taking part in other similar activities.

\section{Perception and attitude changes created by the project}

Forests provide wood and non-wood forest products and services to societies. While wood products were considered to be primary products in the past, it is now a fact that non-wood forest products are primary products in some forest areas (Shackleton and Pandey, 2014). A significant difference was found in this matter between those students who participated in the project and those who did not (Fig. 1). Students who participated in the project think that non-wood forest products and services play a more important role with respect to the benefits of forests. This difference was statistically significant (Table 3). The reason for this difference was that the benefits of forests were addressed thoroughly during the project and students learned it very well. Our results correspond with the findings of Zengin and Kunt (2013). Similarly, a majority of the students who participated in the project emphasized that plants played a crucial role in our daily life whereas there was a relatively higher number of students who did not participate in the project and were indecisive on this matter (Fig. 1). Another reason for that was the insufficient knowledge level of teachers on nature and the environment. Velempini et al. (2017) has reached the point that environmental education topics are not sufficiently included in the curriculum of education and that the teachers in these subjects are also inadequate. This issue can be tackled through training, especially of candidate science teachers about the environment and nature thru active learning techniques and methods (Alkan and Ogurlu, 2014; Uzun and Keles, 2012).

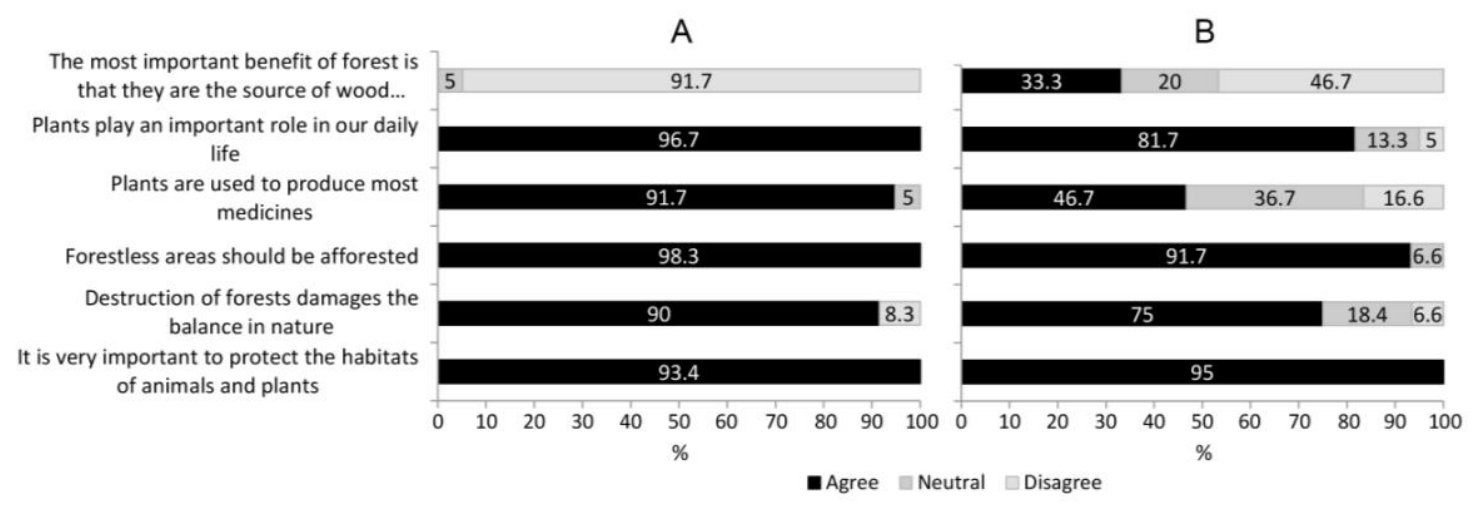

Figure 1. Change in the level of knowledge and awareness about forest and nature $\left(n_{A}=60, n_{B}=60\right.$, only values $\left.\geq 5 \%\right)$

Students who participated in the project had a high knowledge level (91.7\%) about the medical use of plants. More than half of the students who did not participate in the project was neutral $(36.7 \%)$ or did not possess any knowledge $(16.6 \%)$ about this about this matter (Fig. 1). Mann-Whitney U test results (Table 3) show that the differences between the answers of both groups were statistically significant $(\mathrm{p}<0.05)$. The project curriculum included the topic of medical use of plants. 
Table 3. Mann-Whitney $U$ test results for changes in knowledge and awareness about forest and nature

\begin{tabular}{|c|c|c|c|c|c|}
\hline Subjects & Groups & $\mathbf{n}$ & $\begin{array}{c}\text { M-Whitney } \\
\text { U }\end{array}$ & $\mathbf{Z}$ & $\mathbf{p}$ \\
\hline $\begin{array}{l}\text { The most important benefit of forests } \\
\text { is that they are the source of wood } \\
\text { products such as timber and paper. }\end{array}$ & $\begin{array}{c}\text { A } \\
\text { B } \\
\text { Total }\end{array}$ & $\begin{array}{c}60 \\
60 \\
120\end{array}$ & 972.000 & -5.345 & $0.000 *$ \\
\hline $\begin{array}{l}\text { Plants play an important role in our } \\
\text { daily life. }\end{array}$ & $\begin{array}{c}\text { A } \\
\text { B } \\
\text { Total } \\
\end{array}$ & $\begin{array}{c}60 \\
60 \\
120 \\
\end{array}$ & 1513.500 & -2.519 & $0.012 *$ \\
\hline $\begin{array}{l}\text { Plants are used to produce most } \\
\text { medicines. }\end{array}$ & $\begin{array}{c}\text { A } \\
\text { B } \\
\text { Total } \\
\end{array}$ & $\begin{array}{c}60 \\
60 \\
120 \\
\end{array}$ & 997.000 & -5.191 & $0.000 *$ \\
\hline Forestless areas should be afforested. & $\begin{array}{c}\text { A } \\
\text { B } \\
\text { Total } \\
\end{array}$ & $\begin{array}{c}60 \\
60 \\
120 \\
\end{array}$ & 1679.500 & -1.675 & 0.094 \\
\hline $\begin{array}{l}\text { Destruction of forests damages the } \\
\text { balance in nature. }\end{array}$ & $\begin{array}{c}\mathrm{A} \\
\mathrm{B} \\
\text { Total } \\
\end{array}$ & $\begin{array}{c}60 \\
60 \\
120 \\
\end{array}$ & 1555.500 & -1.941 & 0.052 \\
\hline $\begin{array}{l}\text { It is very important to protect the } \\
\text { habitats of animals and plants. }\end{array}$ & $\begin{array}{c}\text { A } \\
\text { B } \\
\text { Total } \\
\end{array}$ & $\begin{array}{c}60 \\
60 \\
120 \\
\end{array}$ & 1769.000 & -0.401 & 0.689 \\
\hline
\end{tabular}

$* \mathrm{p}<0.05$

The students gave positive and similar answers to the following statements: "destruction of forests will damage the natural balance", "afforestation" and "importance of protecting the habitats for wild life and plants" (Fig. 1). This finding indicates that student knowledge and awareness about nature and environmental protection was adequate. Mann-Whitney U test results (Table 3) reveal that there were not statistically significant differences between the students who participated in the project and those who did not $(\mathrm{p}>0.05)$. This finding shows that prior knowledge regarding the importance of nature protection may raise such awareness. Similar results were reported by Ozbas (2013).

Both the students who participated in the project and those who did not stated that "listening to the voices of the organisms in the nature and smells in nature" gave one a peaceful feeling (Fig. 2). Students who participated in the project described the world of plants and insects as mysterious. There were statistically significant differences in the answers to questions on this matter given by the students who participated in the project and those who did not (Table 4). The world of plants and insects was addressed thoroughly during the project and likely facilitated this result.

One of the most important objectives of the project was to encourage the students to inquire and be curious about nature. Theoretical environmental education that is delivered in the form of note-taking is not successful (Ballantyne and Packer, 2002). For success, students should be enabled to have contact with natural and cultural elements, especially through experiential field visits (Jose et al., 2017) and outdoor activities (Jannah et al., 2013; Tesfai et al., 2016). According to Vural and Yilmaz (2016), only $19 \%$ of the positive behaviours of students about environment and nature are based on theoretical information. Practical training was delivered in this project.

A majority of the students who participated in the project agreed with the proposition, "I can walk for several kilometres in the forest to see an endangered plant", while some of the students who did not participate in the project disagreed with this proposition (18.3\%), and 26.7\% was neutral (Fig. 2). The difference between the 
answers of both groups to this proposition was statistically significant (Table 4). Similarly, there was a statistically significant difference $(\mathrm{p}<0.05)$ between the answers given to the proposition, "I would try to prevent anyone from damaging nature" (Table 4 ). This difference is due to the positively changing attitudes towards nature after the practical project training provided. Our results correspond with the findings of Tungac et al. (2017) and Tezel and Karademir (2014) who found that practical trainings given in nature training projects change the opinions of students about nature and forest positively.

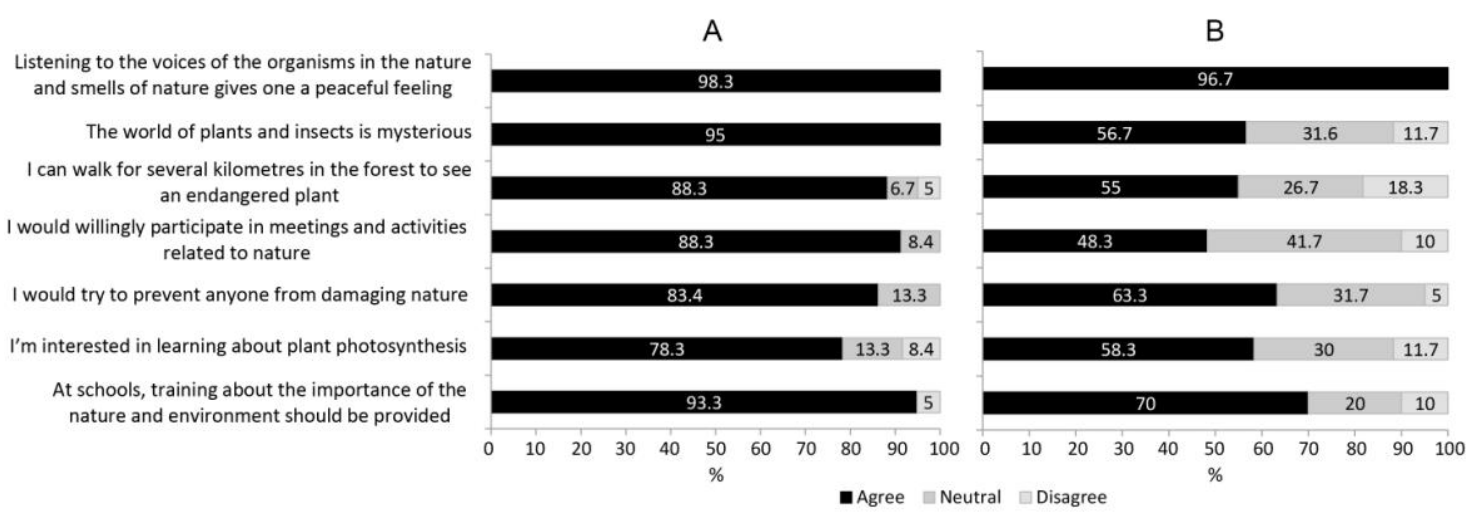

Figure 2. Perception and attitude changes towards nature and environment $\left(n_{A}=60, n_{B}=60\right.$, only values $\left.\geq 5 \%\right)$

Table 4. Mann Whitney-U test results for perception and attitude changes

\begin{tabular}{|c|c|c|c|c|c|}
\hline Subjects & Groups & $\mathbf{n}$ & $\begin{array}{c}\text { M-Whitney } \\
\text { U }\end{array}$ & $\mathbf{Z}$ & $\mathbf{p}$ \\
\hline $\begin{array}{l}\text { Listening to the voices of the } \\
\text { organisms in the nature and smells of } \\
\text { nature gives one a peaceful feeling. }\end{array}$ & $\begin{array}{c}\text { A } \\
\text { B } \\
\text { Total }\end{array}$ & $\begin{array}{c}60 \\
60 \\
120\end{array}$ & 1770.000 & -0.582 & 0.560 \\
\hline $\begin{array}{l}\text { The world of plants and insects is } \\
\text { mysterious. }\end{array}$ & $\begin{array}{c}\text { A } \\
\text { B } \\
\text { Total }\end{array}$ & $\begin{array}{c}60 \\
60 \\
120\end{array}$ & 1125.500 & -4.735 & $0.000 *$ \\
\hline $\begin{array}{l}\text { I can walk for several kilometres in the } \\
\text { forest to see an endangered plant. }\end{array}$ & $\begin{array}{c}\text { A } \\
\text { B } \\
\text { Total }\end{array}$ & $\begin{array}{c}60 \\
60 \\
120\end{array}$ & 1202.000 & -3.968 & 0.000* \\
\hline $\begin{array}{l}\text { I would willingly participate in } \\
\text { meetings and activities related to } \\
\text { nature. }\end{array}$ & $\begin{array}{c}\text { A } \\
\text { B } \\
\text { Total }\end{array}$ & $\begin{array}{c}60 \\
60 \\
120\end{array}$ & 1090.000 & -4.570 & 0.000* \\
\hline $\begin{array}{l}\text { I would try to prevent anyone from } \\
\text { damaging nature. }\end{array}$ & $\begin{array}{c}\text { A } \\
\text { B } \\
\text { Total }\end{array}$ & $\begin{array}{c}60 \\
60 \\
120\end{array}$ & 1447.000 & -2.404 & 0.016 * \\
\hline $\begin{array}{l}\text { I'm interested in learning about plant } \\
\text { photosynthesis. }\end{array}$ & $\begin{array}{c}\text { A } \\
\text { B } \\
\text { Total }\end{array}$ & $\begin{array}{c}60 \\
60 \\
120 \\
\end{array}$ & 1457.000 & -2.200 & $0.028 *$ \\
\hline $\begin{array}{l}\text { At schools, training about the } \\
\text { importance of the nature and } \\
\text { environment should be provided. }\end{array}$ & $\begin{array}{c}\text { A } \\
\text { B } \\
\text { Total }\end{array}$ & $\begin{array}{c}60 \\
60 \\
120\end{array}$ & 1395.000 & -3.156 & 0.002 * \\
\hline
\end{tabular}

$* \mathrm{p}<0.05$

A majority of the students who participated in the project $(88.3 \%)$ stated that they would be willing to participate in training events and activities related to nature. However, the percentage of the students who did not participate in the project and 
agreed with this proposition was low (Fig. 2). The difference between the two groups was significant (Table 4). This finding is important because it indicates that the students participating in the project were satisfied with the training they received and were enthusiastic about participating in future nature and environmental training activities. Willingness can be used as an opportunity to raise motivated and consciousness. Importantly, this will result in students who are determined to respect the environment for a sustainable future (Zsóka et al., 2013).

Education regarding nature and the environment that is provided at schools is inadequate and thus is an important issue. Environmental education is currently incorporated into the science education at schools (Tesfai et al., 2016). However, science education deviates from the goal of developing knowledge and skills related to environmental matters and creating environmentalist behaviours (Wals et al., 2014). The relationship between science and environmental education is characterized as a distant, competitive, predator-prey and host-prey relationship (Gough, 2002). Furthermore, environmental education is transferred superficially and theoretically and thus it cannot ensure the desired behavioural and attitude changes.

Most of the students who participated in the project and those who did not agreed with the proposition, "More comprehensive education regarding the importance of the nature should be provided at schools". This indicates that the education at school was insufficient (Fig. 2). Moreover, the percentage of the students participating in the project who agreed that current environmental education was insufficient was even higher. The difference between the two groups was statistically significant $(p<0.05)$.

A majority of the students who participated in the project $(78.3 \%)$ was interested in photosynthesis. This rate was lower for the students who did not participate in the project. The difference between the two groups was statistically significant $(\mathrm{p}<0.05)$. The most important reason for this was that photosynthesis was explained thoroughly both theoretically and in practical terms during the project and students gained a strong understanding about the importance of how oxygen is produced for our world.

\section{Conclusions}

TUBITAK supports many training projects under the scope of non-formal education. Similar to several other projects, this project was also useful for creating positive perceptions and attitude towards nature and the environment. Therefore, we recommended that such projects should be continued.

The current literature and the findings of this project show that training content, selection of training themes according to the level of the students, duration of the training, competence of the trainers, training methods and effective delivery of the training are important. Additionally, taking necessary steps toward environmental protection and solution of environmental problems and factors play a role in developing positive attitudes and behaviours in individuals. These are important goals and outcomes of environmental education and nature training.

Such training events are very important for promoting environmental awareness and attitudes and need to be developed and planned in terms of content, duration, trainers and practice. In this project, the trainers were selected with due diligence according to the training topics and level of the students.

When students have an opportunity to come into contact with natural objects, this plays a crucial role in creating positive changes regarding nature and the environment in nature 
training projects. In this project, the students were alone in a natural environment for seven days, during which time they engaged with nature and environment utilizing all their senses.

The main success factor for the project came about by presenting the theoretical education provided at schools in a natural environment in the form of practical training, which raised curiosity and interest. Today, due to urbanization, children who are not raised in a rural environment no longer experience the pleasure of communing with nature.

According to the research findings, the selection of sixth grade students as the target group was appropriate. Students who participated in the project developed more positive environmental awareness and attitudes compared to those who did not participate. Moreover, the project also contributed to the raising of awareness, curiosity and improvement of knowledge level regarding nature and the environment.

Subsequent generations can be made more conscious about nature and the environment through similar projects. This would be especially the case if nature and environmentoriented practical training is incorporated into the formal education curricula. Importantly, it is critical to monitor and evaluate the training to identify long-term effects.

Teachers are among the most important elements of the teaching-learning process and should also be trained regarding environmental education. This training of teachers will disseminate the effect of the projects with a multiplying effect. In other words, the environmental education at schools will become more effective in this way. Teachers who are willing to learn about plants, animals, and habitats will transfer such knowledge to their students.

Further research should be conducted on how students' environmental attitudes are reflected in their behaviours. In addition, projects and researches should be carried out to raise awareness about current environmental problems.

Acknowledgements. This project which was supported by TUBITAK was realized with a wide scoped participating crew. We hereby present our gratitude to everyone who has provided contribution to our project and, TUBITAK.

\section{REFERENCES}

[1] Alkan, H., Ogurlu, İ. (2014): Changes in the environmental perception, attitude and behaviour of participants at the end of nature training projects. - Environmental Engineering and Management Journal 13(2): 419-428.

[2] Atasoy, E. (2006): Cevre icin egitim: cocuk ve doga etkilesimi (in Turkish). - Ezgi Publishing, Turkey.

[3] Ballantyne, R., Packer, J. (2002): Naturebased excursions: school students' perceptions of learning in natural environments. - International Research in Geographical and Environmental Education 11(3): 218-236.

[4] Çimen, O., Yılmaz, M. (2014): The influence of transformative learning based environmental education on preservice biology teachers' perception of environmental problems. - Bartın University Journal of Faculty of Education 3(1): 339-359.

[5] Damerell, P., Howe, C., Milner-Gulland, E.J. (2013): Child-orientated environmental education influences adult knowledge and household behaviour. - Environ. Res. Lett. 8: (015016):1-7.

[6] Davis, P.H., Tan, K., Mill, R. (1970): Flora of Turkey and the Aegean Islands, Vol. :III, p.45,46, Edinburgh Univ. Press., London.

[7] Erten, S. (2005): Investigation of preservice preschool teachers' behaviors related to environmental awareness. - Hacettepe University Journal of Education 28: 92-100. 
[8] Geray, C. (1998): Local governments and the environment. - Journal of Contemporary Local Governments 7(3): 57-65.

[9] Gough, A. (2002): Mutualism: A different agenda for environmental and science education. - International Journal of Science Education 24(11): 1021-1215.

[10] Güler, T. (2009): The effects of an ecology based environmental education on teachers' opinions about environmental education. - Education and Science 34(151): 30-43.

[11] Güven, E. (2014): The effect of project based learning method supported by prediction observation - explanations on the attitude and behaviors towards environmental problems. - Education and Science 39(173): 25-38.

[12] Harlen, W., Qualter, A. (2014): The teaching of science in primary schools. $-6^{\text {th }}$ edition, Abington: Routledge.

[13] Jannah, M., Halim, L., Meerah, T.S.M., Fairuz, M. (2013): Impact of environmental education kit on students' environmental literacy. - Asian Social Science 9(12): 1-12.

[14] Jose, S., Patrick, P.G., Moseley, C. (2017): Experiential learning theory: The importance of outdoor classrooms in environmental education. - International Journal of Science Education Part B 7(3).

[15] Malone, K., Tranter, P. (2003): Children's environmental learning and the use, design and management of schoolgrounds. - Children, Youth and Environments 13(2): 1-30.

[16] Mamikoglu, N.G. (2007): Turkiye'nin Agac ve Calilari (in Turkish). - NTV Publishing, Turkey.

[17] Milton, B., Cleveland, E., Bennett-Gates, D. (1995): Changing perceptions of nature, self, and others: A report on a park/school program. - Journal of Environmental Education 26(3): 32-42.

[18] Noughton-Treves, L., Holand, M.,Brondon, K. (2005): The role of protected areas in conserving biodiversity and sustaining local livelihoods. - Annual review of environment and resources 30: 219-252.

[19] Ogurlu, İ. (2016): Evaluation of effects on participants of a nature training projects. - Bati Anadolu Egitim Bilimleri Dergisi 07(14): 59-101.

[20] Ozbas, S. (2013): Attitudes of middle school students towards the forests in Nicosia Sakarya University Journal of Education, 3(3): 82-94.

[21] Palmberg, I, E., Kuru, J. (2001): Children and nature. ATEE 26th Annual Conference: RDC 17: Environmental Education.

[22] Phenice, L. A., Griffore, R. J. (2003): Young children and the natural world. Contemporary Issues in Early Childhood, Sage Journals 4(2): 167-171.

[23] Poortinga, W., Steg, L., Vlek, C. (2004): Values, environmental concern and environmental behavior. - Environment and Behavior 36(1): 70-93.

[24] Shackleton, C.M., Pandey, A.K. (2014): Positioning non-timber forest products on the development agenda. - Forest Policy and Economics 38: 1-7.

[25] Soran H., Morgil I., Yücel S.E., Isık S. (2000): Biyoloji ögrencilerinin çevre konularına olan ilgilerinin arastırılması ve kimya ögrencileri ile karsılastırılması (in Turkish). - HU Journal of Education 18: 128-139.

[26] Tanriverdi, B. (2009): Analyzing primary school curriculum in terms of sustainable environmental education. - Education and Science 34(151): 89-103.

[27] Tesfai, M., Nagothu, U.S., Simek, J., Fucik, P. (2016): Perceptions of secondary school students' towards environmental services: A case study from Czechia. - International Journal of Environmental \& Science Education 11(12): 5533-5553.

[28] Tezel, O., Karademir, E. (2014): The change of secondary school students environmental attitude, behavior and thoughts with nature training project - International Conference on Education in Mathematics, Science \&Technology, May 16-18, 2014, Konya, Turkey, pp. 1239-1243.

[29] Tlert R. (1998): Environmental education and supplement. - Cev-Kor 7: 3-9. 
[30] Tungac, A.S., Yaman, S., Incebacak, B.N. (2017): The effect of environmental education projects on third grade primary school students' attitudes towards forest - Journal of Subject Teaching Research 3(1): 41-50.

[31] Uzun, F. V., Keles, O. (2012): The effects of nature education project on the environmental awareness and behavior. - Procedia - Social and Behavioral Sciences 46: 2912-2916.

[32] Velempini, K., Martin, B., Smucker, T., Randolph, A.W., Hennig, J.H. (2017): Environmental education in southern Africa: a case study of a secondary school in the Okavango Delta of Botswana. - Environmental Education Research, DOI: 10.1080/13504622.2017.1377158: 1-17.

[33] Vural, H., Y1lmaz, S. (2016): Determining the knowledge and level of attitudes of the secondary school students to environment and nature; a case of Erzurum - Iğdır Univ. J. Inst. Sci. \& Tech. 6(1): 107-115.

[34] Wals, A.E.J., Brody, M., Dillon, J., Stevenson, R.B. (2014): Convergence between science and environmental education. - Science 344(6184): 583-584.

[35] Yıldırım, E.G., Köklükaya, A.N. (2016). Determination of primary and secondary school students' interest level toward the science topics. - Amasya Education Journal 5(1): 1-22.

[36] Yilmaz A., Morgil I., Aktug P., Göbekli I. (2002): Knowledge of the secondary school and university students on the environment, environmental concepts and problems and suggestions. - HU Journal of Education 22: 156-162.

[37] Zengin, U., Kunt, H. (2013): An analysis of secondary school students' attitudes towards trees and environment. - Mustafa Kemal University Journal of Social Sciences Institute 10(23): 155-165.

[38] Zsóka, Á, Szerényi, Z.M., Széchy, A., Kocsis, T. (2013): Greening due to environmental education? Environmental knowledge, attitudes, consumer behavior and everyday proenvironmental activities of Hungarian high school and university students. - Journal of Cleaner Production 48: 126-138. 